\title{
Studi Pola Sebaran Suhu Permukaan Laut Akibat Air Bahang Pembangkit Listrik Tenaga Uap (PLTU) Paiton Probolinggo Jawa Timur
}

\author{
Karunia Lasmarito Pintubatu*, Sugeng Widada, Jarot Marwoto, Alfi Satriadi \\ Departemen Oseanografi, Fakultas Perikanan dan Ilmu Kelautan, Universitas Diponegoro \\ Jl. Prof.H.Soedarto S.H, Tembalang,Semarang, Jawa Tengah 50275 Indonesia \\ Email : *niapintubatu@gmail.com
}

\begin{abstract}
Abstrak
PLTU Paiton memanfaatkan air laut sebagai pendingin kondensor (air bahang) yang menghasilkan air bahang, yakni air buangan yang sebelumnya terpakai yang memiliki kondisi nilai suhu lebih tinggi dibanding suhu perairan di sekitarnya. Penelitian ini bertujuan untuk mengetahui pola sebaran suhu permukaan laut akibat air bahang PLTU Paiton Probolinggo secara horizontal. Data yang digunakan dalam penelitian ini adalah Citra Landsat 8 TIRS perekaman 20 November 2019, suhu permukaan laut lapangan, arus permukaan laut lapangan, data curah hujan dari stasiun lokal PT.POMI Unit 7 dan 8, data pasang surut yang diterbitkan oleh PUSHIDROSAL, data Indian Ocean Dipole (IOD), dan peta RBI yang diterbitkan oleh Badan Informasi Geospasial (BIG). Metode yang digunakan dalam penelitian ini adalah metode deskriptif, sedangkan metode yang digunakan untuk menentukan stasiun penelitian di lapangan adalah metode purposive sampling. Hasil pengolahan data suhu permukaan lapangan 20 November 2019 menunjukkan nilai suhu pada discharge canal sebesar $33^{\circ}-34^{\circ} \mathrm{C}$. Sementara Hasil perekaman citra pada 20 November 2019 menunjukkan suhu akibat air bahang dengan nilai $33^{\circ}-34^{\circ} \mathrm{C}$ memiliki luas area 15,89 ha dan jarak terhadap tegak lurus pantai adalah $0,15 \mathrm{~km}$. Suhu akibat air bahang dengan nilai $31^{\circ}$ $-32^{\circ} \mathrm{C}$ memiliki luas area 140,35 ha dan jarak tegak lurus pantai adalah $0,2 \mathrm{~km}$. Nilai RMSE antara suhu permukaan laut lapangan dengan perekaman Citra Landsat 8 TIRS sebesar 0.621388. Sebaran suhu permukaan laut di perairan PLTU Paiton dipengarui oleh arus yang bersifat pasang surut, cenderung bergerak ke arah UtaraTimur Laut dari discharge canal PLTU dengan kecepatan rerata kecepatan arus dari sekitar 0.6-1.2 m/s untuk komponen zonal dan sekitar $0.45 \mathrm{~m} / \mathrm{s}$ untuk komponen meridional.
\end{abstract}

Kata Kunci : Air Bahang, Suhu Permukaan Laut, Landsat 8 TIRS

\begin{abstract}
The Steam Electricity Power Plant Paiton Probolinggo uses sea water on its operational activity as cooler condencor, which produces hot water. Hot water is previously used water that has a condition, higher temperature that can lead increasing sea surface temperature in the surrounding waters. The objective this research is to know the sea surface temperature patterns of Steam Electricity Power Plant Paiton Probolinggo. To carry out the study used data include Landsat 8 TIRS Imagery, sea surface temperature, sea level currents from field, rainfall gotten from PT.POMI Unit 7 and 8 local station, tides from PUSHIDROSAL, Index Dipole Mode which downloaded from JAMSTEC and RBI maps from BIG. The research method used is descriptive method, while for the method in determining the sampling station using purposive sampling method. The Result from sea surface temperature on 20 November 2019 is showed that the temperature of the discharge canal was $33^{\circ}-34^{\circ} \mathrm{C}$. The result of imagery recording on 20 November 2019 showed that its temperature also about $33^{\circ}-34^{\circ} \mathrm{C}$, with an area of 15,89 ha and distance of $0,15 \mathrm{~km}$, and was $31^{\circ}-32^{\circ} \mathrm{C}$ with area of 140,35 ha and distance of 0,2 km. RMSE value between sea surface temperature field and Landsat 8 TIRS imagery is 0.621388 . The distribution of sea surface temperature is influenced by tidal currents leading to North-Northeast from discharge canal of PLTU with current velocity of 0.6-1.2 m.s for zonal component and about $0.45 \mathrm{~m} / \mathrm{s}$ for meridional component.
\end{abstract}

Keywords : Hot Water, Sea Surface Temperature, Landsat 8 TIRS Image 


\section{PENDAhUluan}

Kabupaten Probolinggo merupakan salah satu kabupaten di Jawa Timur dengan letak astronomis berada pada posisi $7^{\circ} 40^{\prime}-8^{\circ} 10^{\prime}$ LS dan $112^{\circ} 50^{\prime}-113^{\circ} 30^{\prime}$ BT. Panjang garis pantai Kabupaten Probolinggo adalah 72,110 km (Profil Desa, 2017). Kabupaten Probolinggo merupakan salah satu kabupaten yang memiliki PLTU yaitu PLTU Paiton. PLTU Paiton merupakan PLTU terbesar di JawaBali yang terletak di Jalan Raya Surabaya - Situbondo km 142 Paiton, Probolinggo.

PLTU Paiton merupakan PLTU terbesar di Asia Tenggara, memiliki 8 unit dengan kapasitas 4972 MW yang dapat mendistribusikan listrik ke Pulau Jawa-Bali. Sistem kerja PLTU dalam memproduksi listrik yakni dengan memanfaatkan air laut sebagai pendingin kondensor (air bahang) yang akhirnya dibuang ke laut melalui Discharge Canal (DC) dengan suhu lebih tinggi dibandingkan dengan suhu perairan sekitar. Batas suhu air bahang yang diperbolehkan dibuang ke laut, berdasarkan KepMenLH No. $363 / 2013$ adalah $40^{\circ} \mathrm{C}$, maka apabila kondisi suhu perairan melebihi baku mutu, akan memberikan dampak negatif terhadap kualitas air laut, ekosistem dan kehidupan serta aktivitas lainnya di sekitar perairan. Berdasarkan penelitian Ismayati dkk (2013), menyatakan bahwa nilai suhu permukaan laut akibat sebaran air bahang PLTU Paiton Probolinggo adalah $34^{\circ} \mathrm{C}-35^{\circ} \mathrm{C}$

Buangan air bahang yang keluar dari DC akan mengalami proses dispersi yang lama sehingga bercampur dengan air laut dan tersebar mengikuti pergerakan arus dan pasang surut. Selain itu, terdapat pengaruh dari gesekan dasar perairan, interaksi antara atmosfer dan permukaan laut Menurut Fernandes (2005), proses hidrodinamika di estuari bersifat kompleks dan tidak linear. Sedangkan untuk proses transport panas di laut oleh adveksi cenderung dipengaruhi oleh arus laut (Panalaran, 2012).

\section{MATERI DAN METODE PENELITIAN}

\subsection{Materi Penelitian}

Materi yang digunakan dalam penelitian ini dibagi menjadi dua yakni data primer yang terdiri dari data arus dan suhu permukaan laut. Sedangkan data sekunder terdiri dari data Citra Landsat 8 TIRS, pasang surut, curah hujan lokal, Index Ocean Dipole (IOD), dan Peta Rupa Bumi Indonesia (RBI) skala $1: 25.000$.

\section{A. Metode Penelitian}

Metode yang digunakan untuk menentukan lokasi penelitian adalah dengan metode purposive sampling yakni metode dengan berdasarkan kriteria dan tujuan tertentu (Sugiyono, 2008). Sedangkan metode penelitian yang digunakan adalah metode deskriptif. Metode deskriptif adalah metode penelitian untuk membuat gambaran terhadap kejadian atau situasi yang diteliti pada waktu terbatas dan wilayah tertentu untuk mendapatkan gambaran situasi dan kondisi secara lokal.

\section{Pengukuran Suhu Permukaan Laut Lapangan}

Pengambilan data suhu permukaan laut dilakukan menggunakan CTD yang dicelupkan sampai menyentuh dasar perairan di setiap titik stasiun kemudian CTD diangkat kembali ke permukaan. Instrumen CTD akan melakukan perekaman data suhu permukaan laut di 10 titik stasiun di Discharge Canal (DC) atau kanal buangan air bahang setiap 0,03 detik sedangkan untuk perekaman data suhu spasial, dilakukan setiap 0,1 detik. Pengambilan data suhu permukaan laut dilakukan di perairan PLTU Paiton pada pukul 10.23-11.00 WIB dengan kondisi perairan surut menuju pasang.

\section{Tahap Pengolahan \\ Pengukuran Arus Laut}

Pengambilan data arus permukaan lapangan dilakukan menggunakan Electromagnetic Recording Current Meter (ECM). Variabel yang diukur adalah kecepatan dan arah arus. Pengambilan data dilakukan pada tanggal 19 November 2019, pada pukul 09.00-11.05 WIB di Discharge Canal (DC) dan pada pukul 11.33- 13.36 di Suar PLTU Paiton. Data arus berupa komponen kecepatan dan arah arus diolah menggunakan Ms.Excel untuk melihat dominan arah arus bergerak pada musim Peralihan II.

\section{Pasang Surut}

Data pasang surut yang digunakan adalah data yang diterbitkan oleh Pusat Hidro-Oseanografi TNI Angkatan Laut (PUSHIDROSAL), diperoleh dari PT Paiton Operation and Maintenance Indonesia (PT. POMI) Unit 7 dan 8, dengan lokasi stasiun Probolinggo yang diambil selama 30 hari yakni pada 
tanggal 01-30 November 2019. Data tersebut diolah menggunakan metode peramalan Admiralty untuk menghasilkan nilai komponen pasang surut utama

\section{Curah Hujan}

Data curah hujan yang digunakan adalah data curah hujan lokal sepanjang 2019 yang diperoleh dari PT POMI Unit 7 dan 8. Data tersebut diolah dengan menggunakan Ms. Excel sehingga diperoleh hasil berupa grafik yang menunjukkan pola intensitas curah hujan yang turun sepanjang tahun 2019 di wilayah PLTU Paiton.

IOD

Nilai IOD diunduh melalui website Japan Agency for Marine-Earth Science and Technology (JAMSTEC) melalui http://www.jamstec.go.jp/e/. Nilai IOD yang diunduh adalah nilai IOD selama 9 tahun yaitu dari tahun 2010-2019. Hal tersebut bertujuan untuk mengetahui trend nilai IOD yang kemudian dapat menjadi variabel penentu terjadinya La-Nina atau El-Nino yang berdampak pada pola curah hujan.

\section{Citra Landsat 8 TIRS}

Citra Satelit Landsat 8 TIRS diunduh melalui situs USGS pada laman earthexplorer.usgs.gov, dengan path/row 118/65 untuk menampilkan wilayah perairan PLTU Paiton Probolinggo dengan perekaman pada tanggal 19 November 2019. Pada pengolahan Citra Satelit Landsat 8 TIRS, kanal yang digunakan adalah kanal 11. Hal tersebut untuk mendapatkan nilai yang merupakan kanal inframerah termal dengan panjang gelombang 10,60-11,19 $\mu \mathrm{m}$.

\section{Tahap Validasi}

Validasi merupakan suatu tindakan pembuktian dengan metode yang sesuai bahwa setiap proses atau mekanisme yang digunakan dalam suatu percobaan atau penelitian mencapai hasil yang diinginkan/mendekati nilai kebenaran seharusnya. Dalam penelitian ini, validasi dilakukan untuk menghitung nilai Root Mean Square Error (RMSE) menggunakan nilai suhu permukaan laut hasil pengukuran di lapangan serta nilai suhu hasil pengolahan Citra Landsat 8 TIRS.

Menurut Bambang Triatmodjo (1999) besar kesalahan dapat dihitung menggunakan persamaan sebagai berikut :

$$
R M S E=\frac{1}{n} \sum_{t=1}^{n}\left\|\frac{p-p^{*}}{p}\right\|
$$

Adapun $\mathrm{n}, \mathrm{p}$ dan $\mathrm{p}^{*}$ masing-masing merupakan jumlah data, data lapangan dan data hasil pengerjaan citra

\section{HASIL DAN PEMBAHASAN}

\section{A. Suhu Permukaan Laut}

Tabel 1 menunjukkan hasil verifikasi dengan nilai RMSE yang dilakukan antara data pengukuran lapangan dan Citra Landsat 8 TIRS. Nilai error pada stasiun satu sebesar 0.175 , pada stasiun dua sebesar 0.22, pada stasiun tigasebesar 0.36, pada stasiun empat sebesar 0.14, pada stasiun lima sebesar 0.12 , pada stasiun enam sebesar 0.14 , pada stasiun tujuh sebesar 0.11 , pada stasiun delapan sebesar 0.18, pada stasiun sembilan sebesar 0.24 dan pada stasiun sepuluh sebesar 0.30. Nilai RMSE rerata hasil perhitungan data lapangan dan perekaman 20 November 2019 diperoleh sebesar 0.6213. 


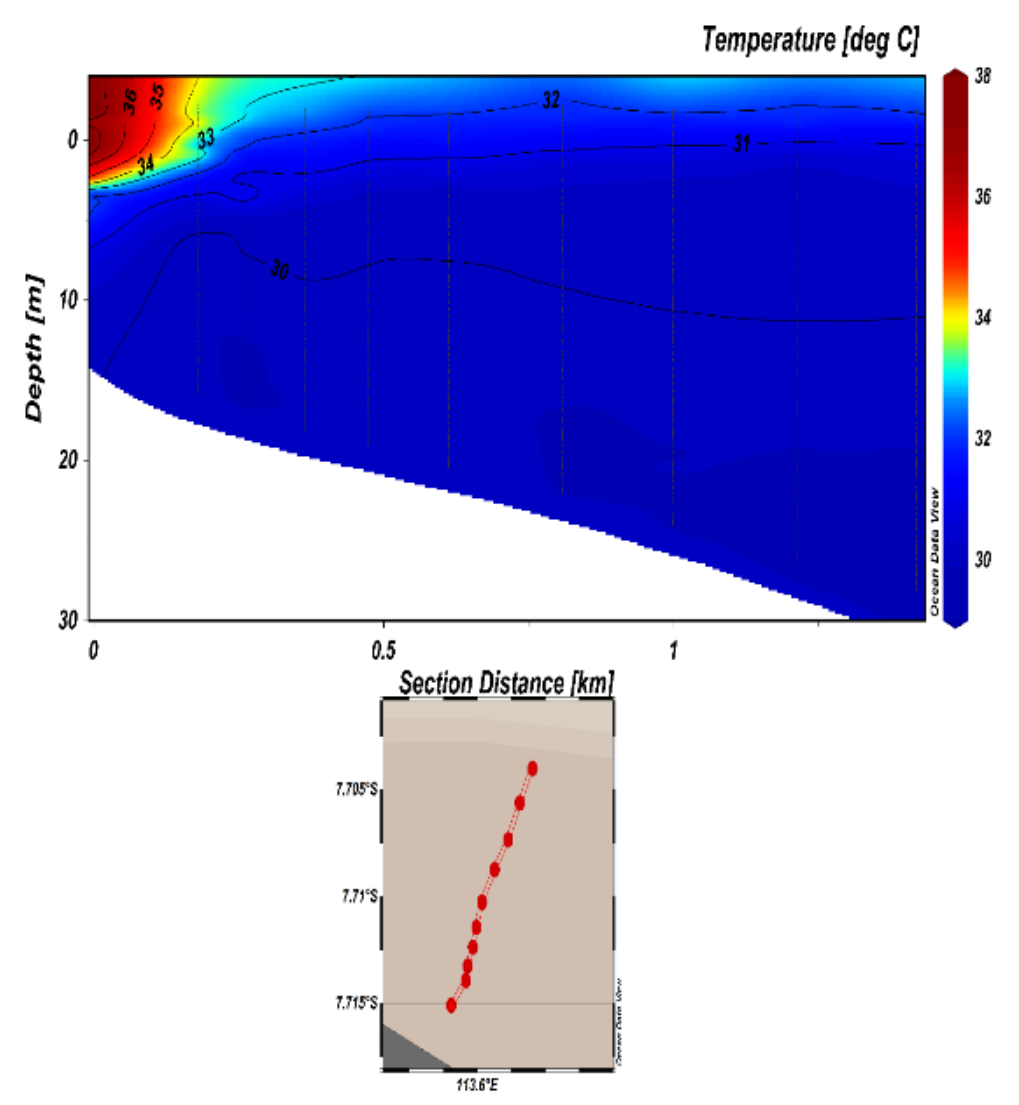

Gambar 1. Sebaran Suhu Permukaan Laut Lapangan 10 Stasiun 20 November 2019.

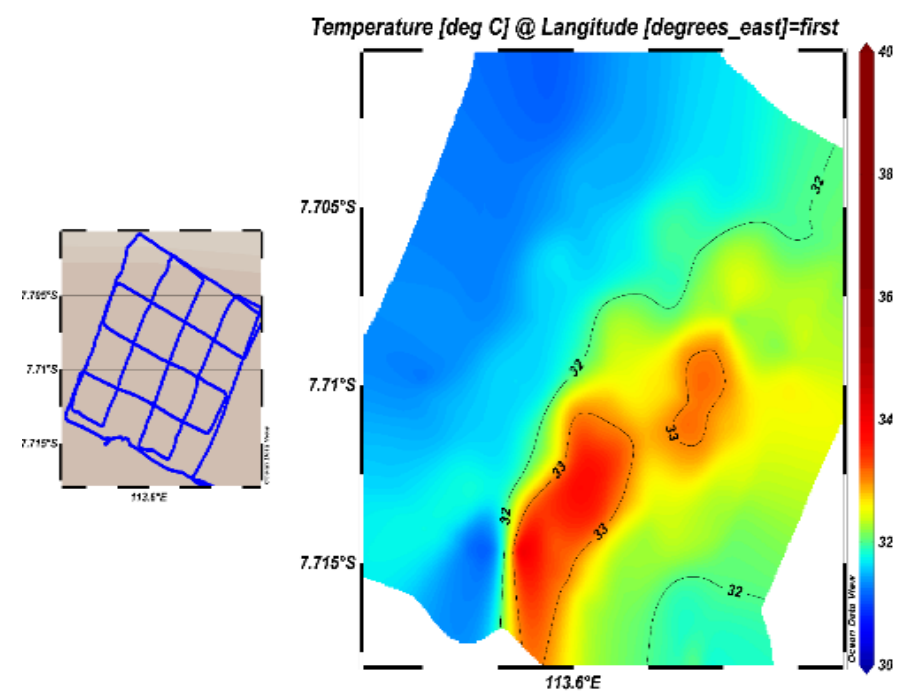

Gambar 2. Sebaran Suhu Permukaan Laut Spasial Lapangan 20 November 2019. 


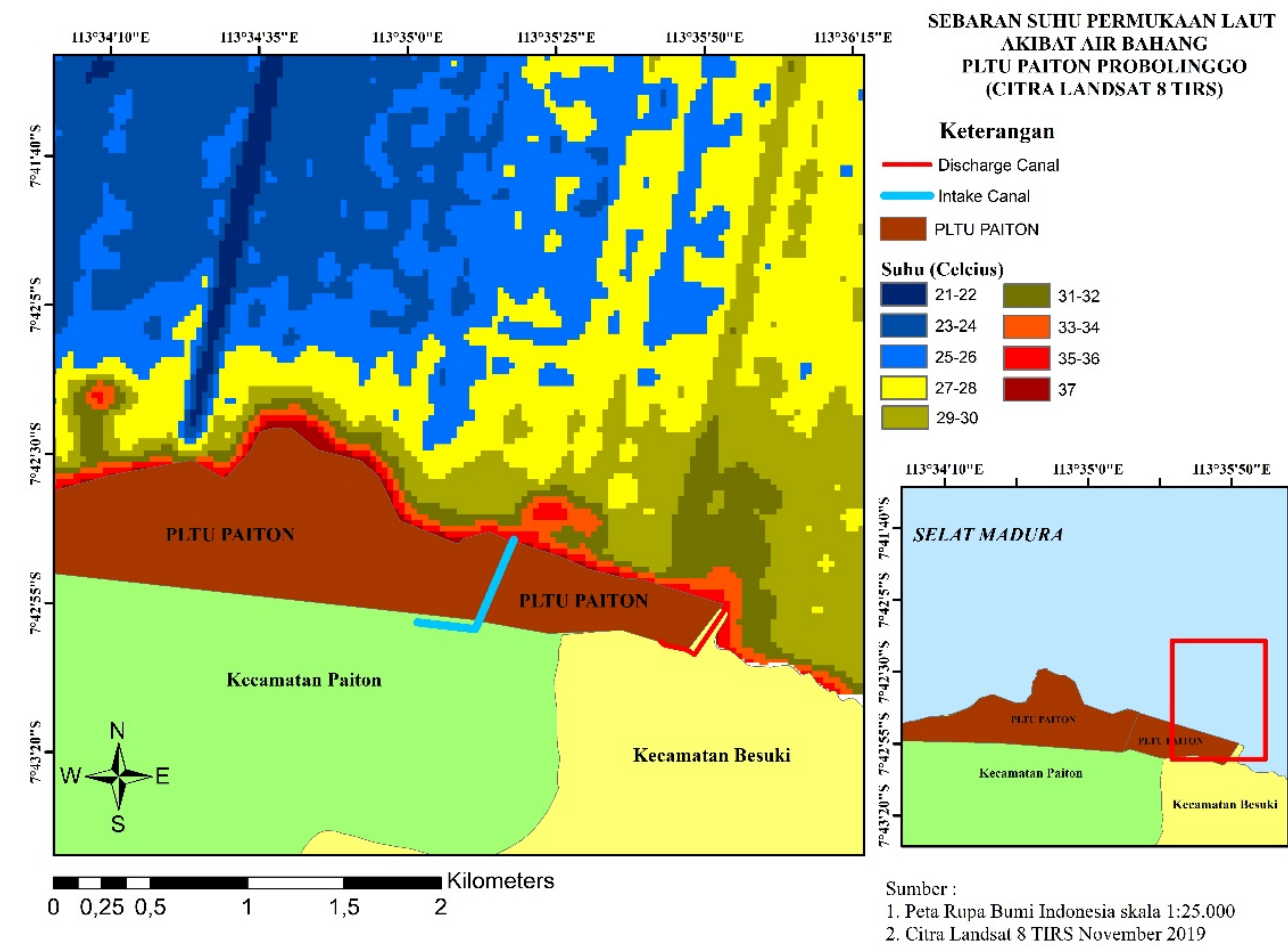

Gambar 3. Peta Sebaran Suhu Permukaan Laut Pengolahan Citra Landsat 8 TIRS 20 November 2018.

Tabel 1. Nilai RMSE Suhu Permukaan Laut 20 November 2019

\begin{tabular}{cccccc}
\hline Stasiun & Longitude & Latitude & \multicolumn{2}{c}{ Nilai Suhu } & \multirow{2}{*}{ RMSE } \\
\cline { 4 - 5 } & & & Lapangan & Citra & \\
\cline { 4 - 5 } 1 & -7.7151 & 113.59808 & 34.29 & 34.12 & 0.175 \\
2 & -7.71394 & 113.59915 & 31.69 & 31.91 & 0.22 \\
3 & -7.71326 & 113.59927 & 30.51 & 30.87 & 0.36 \\
4 & -7.71237 & 113.59968 & 30.35 & 30.47 & 0.12 \\
5 & -7.71143 & 113.59994 & 30.32 & 30.2 & 0.12 \\
6 & -7.71026 & 113.60036 & 30.26 & 30.4 & 0.14 \\
7 & -7.70875 & 113.60129 & 30.2 & 30.31 & 0.11 \\
8 & -7.70734 & 113.60226 & 30.22 & 30.42 & 0.18 \\
9 & -7.70563 & 113.60312 & 30.57 & 30.33 & 0.24 \\
10 & -7.70401 & 113.60407 & 30.67 & 30.37 & 0.3 \\
& & & & RMSE & 0.621388 \\
& & & & Rerata & \\
\hline
\end{tabular}

\section{B. IOD}

Data IOD yang diunduh melalu http://www.jamstec.go.jp/e/, diolah menggunakan Ms. Excel 2010 sehingga diperoleh hasil berupa grafik trend IOD tahun 2010-2019. 


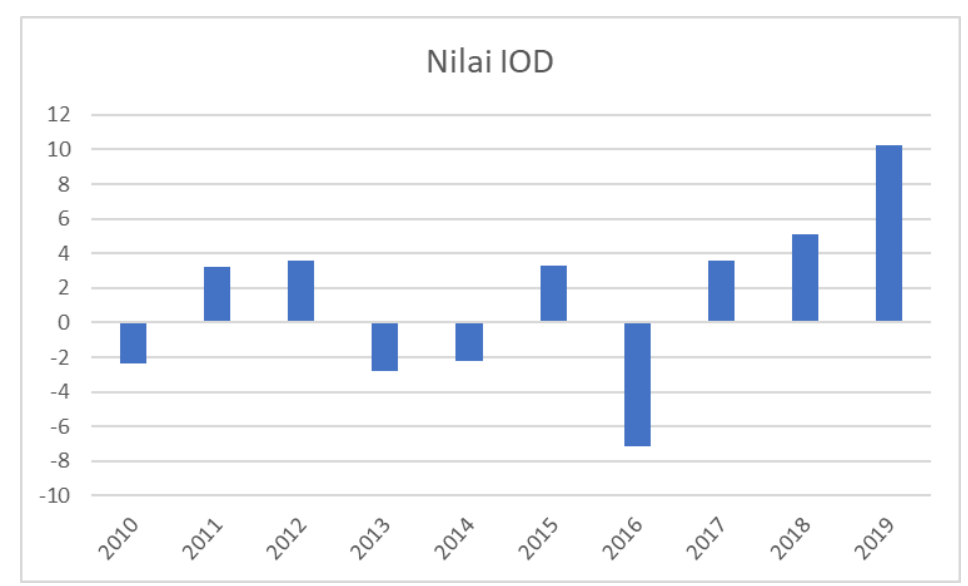

Gambar 4. Diagram IOD 2010-2019

\section{Curah Hujan}

Data curah hujan diperoleh dari stasiun lokal PT.POMI Unit 7 dan 8, Probolinggo. Intensitas curah hujan tertinggi terjadi pada bulan Februari, 2019 yaitu sebesar $547 \mathrm{~mm}$. Sedangkan intensitas curah hujan terendah terjadi di bulan Juni, Agustus, September, Oktober dan November, ditandai dengan tidak adanya curah hujan yang turun $(0 \mathrm{~mm})$.

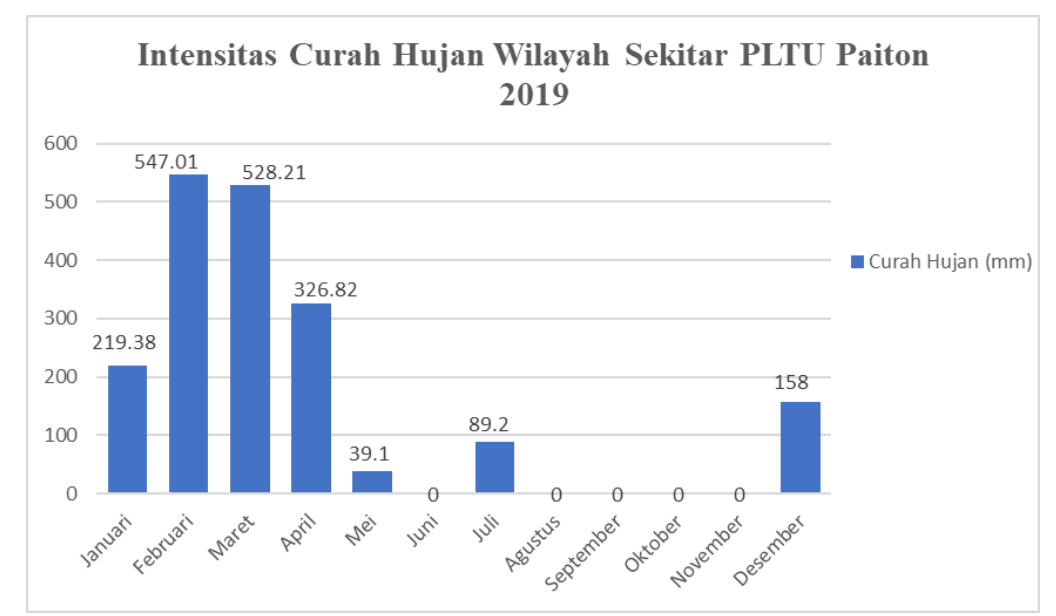

Gambar 5. Diagram Curah Hujan 2019 Lokasi PLTU Paiton

\section{Pasang Surut}

Berdasarkan hasil pengolaha data pasang surut yang telah dilakukan, diperoleh nilai MSL sebesar $164.74 \mathrm{~cm}$, HHWL sebesar $182.65 \mathrm{~cm}$ dan LLWL sebesar $15.915 \mathrm{~cm}$. Sementara nilai Formzhal yang diperoleh adalah sebesar 0.9912. Berdasarkan klasifikasi nilai Formzhal, maka tipe pasang surut perairan PLTU Paiton tergolong tipe pasang surut campuran condong harian ganda. Hal tersebut sesuai dengan pernyataan Fadillah dkk (2014), yang menyatakan bahwa apabila nilai Formzhal 1,50<F $\leq 3,0$, maka tipe pasang surut perairan termasuk dalam tipe campuran condong harian ganda. 


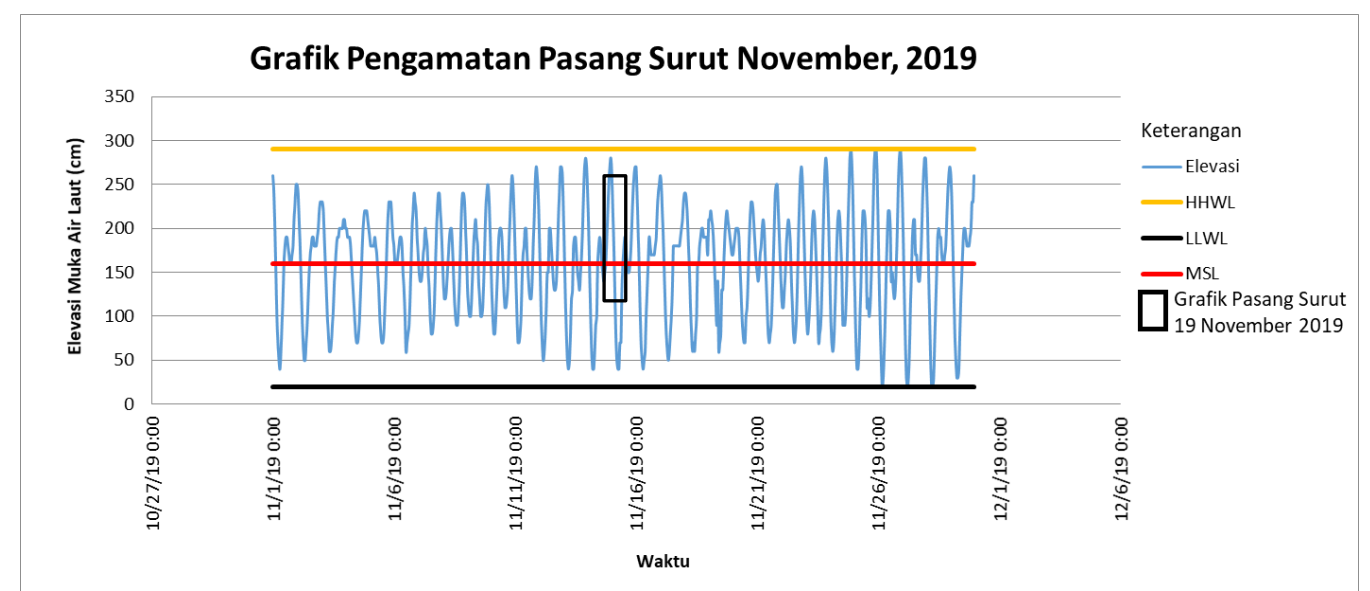

Gambar 6. Grafik Pasang Surut November, 2019

\section{E. Arus Laut}

Hasil data lapangan 19 November 2019 di lokasi Suar menunjukkan awal pengukuran kecepatan arus tercatat sekitar $0.09 \mathrm{~m} / \mathrm{s}$ yang berfluktuasi dalam rentang nilai tersebut sampai akhir pengukuran. Kemudian kecepatan arus meningkat menjadi $0.2 \mathrm{~m} / \mathrm{s}$ sampai akhir pengukuran. Arah arus relatif stabil ke arah Barat-Barat Laut. Fluktuasi kecepatan dan arah arus yang diukur Discharge Canal menunjukkan fluktuasi di nilai rerata kecepatan arus dari sekitar 0.6-1.2 m/s untuk komponen zonal dan sekitar 0.45 $\mathrm{m} / \mathrm{s}$ untuk komponen meridional. Arah arus cenderung stabil ke arah sekitar $45^{\circ}-50^{\circ}$ atau ke arah Timur Laut.

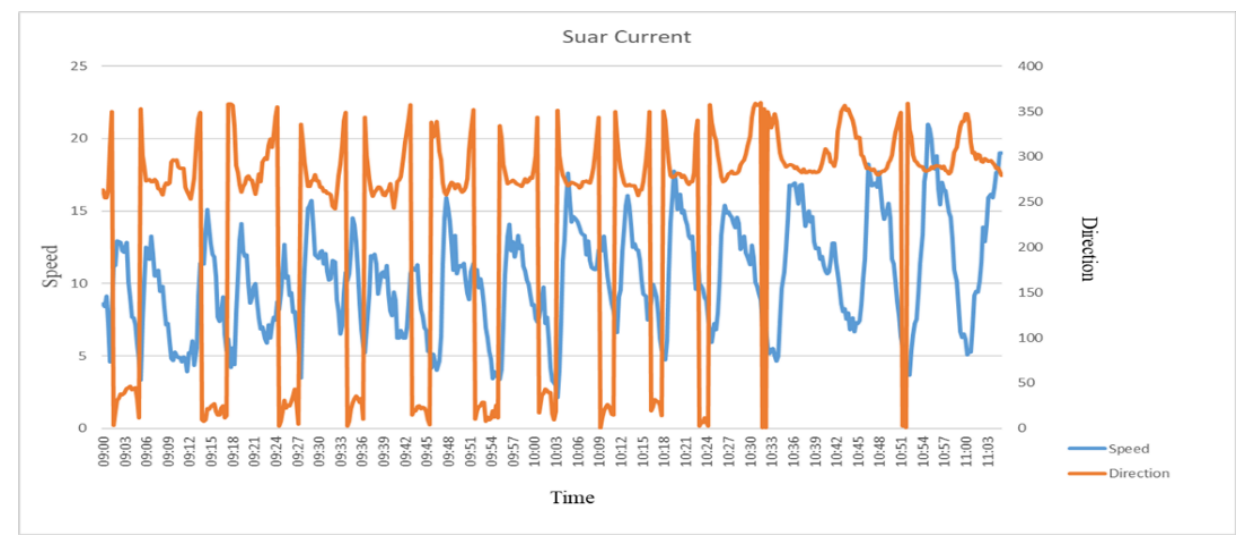

Gambar 7. Grafik Arus Lokasi Penelitian Suar PLTU Paiton, 19 November 2019 


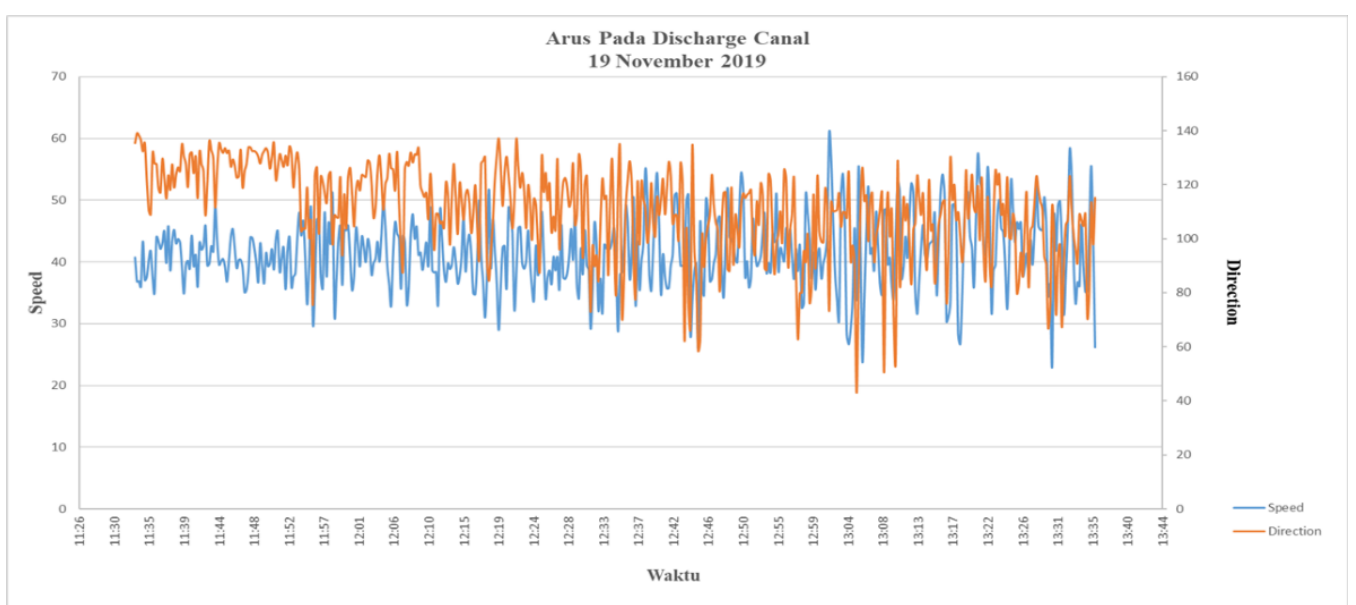

Gambar 8. Grafik Arus Lokasi Penelitian Discharge Canal PLTU Paiton, 19 November 2019

Data suhu permukaan laut hasil pengambilan di lapangan pada 10 titik stasiun (Gambar 13 dan Gambar 14), menunjukkan bahwa suhu permukaan laut DC akibat air bahang ditunjukkan oleh warna merah dengan nilai suhu air bahang sekitar $35^{\circ}-36^{\circ}$ dan orange dengan rentang nilai sekitar $33^{\circ}-34^{\circ}$ $\mathrm{C}$, dan warna hijau tua-hijau muda menunjukkan nilai suhu permukaan laut sekitar $30^{\circ}-33^{\circ} \mathrm{C}$. Hasil pengolahan data suhu permukaan laut lapangan spasial (Gambar 14) menunjukkan suhu permukaan laut didominasi oleh warna merah dan hijau. Klasifikasi warna merah tua menunjukkan nilai suhu air bahang pada daerah di sekitar DC adalah $35^{\circ}-36^{\circ} \mathrm{C}$, warna orange menunjukkan nilai suhu permukaan laut sekitar $33^{\circ}-34^{\circ} \mathrm{C}$ dan warna hijau muda-hijau tua menunjukkan nilai suhu permukaan laut sebesar $30^{\circ}$ $-32^{\circ} \mathrm{C}$. Berdasarkan hasil pengolahan Citra Landsat 8 TIRS perekaman 20 November 2019 maupun pengolahan data lapangan 20 November 2019, menunjukkan nilai suhu air bahang di DC tidak jauh berbeda yakni berada pada rentang nilai suhu permukaan laut $35^{\circ}-36^{\circ} \mathrm{C}$, dan nilai suhu permukaan laut dengan jarak sekitar $0.3 \mathrm{~km}$ dari pantai yakni $32^{\circ}-34^{\circ} \mathrm{C}$ Tingginya nilai suhu permukaan laut PLTU Paiton tersebut diduga terjadi karena pada bulan November termasuk kedalam musim peralihan dua, dimana angin akan bertiup dari arah Tenggara atau daratan Australia ke Benua Asia sehingga terjadi sedikit musim hujan. Hal tersebut juga diketahui pada bulan November 2019 berdasarkan nilai intensitas curah hujan yakni sebesar 0 yang berarti bahwa selama bulan November 2019 tidak terjadi hujan. Menurut Yananto dan Sibarani (2016), curah hujan yang tidak begitu banyak merupakan salah satu faktor penyebab keadaan perairan akan terasa lebih hangat.

Diketahui bahwa nilai IOD sepanjang tahun 2019 bernilai 10.2, dan nilai IOD pada bulan November 2019 bernilai 2.3 yang menunjukkan bahwa berkurangnya curah hujan yang turun pada periode tersebut. Berkurangnya intensitas curah hujan yang turun diakibatkan oleh terjadinya anomali positif angin tenggara saat Dipole Mode berlangsung sehingga angin tenggara yang berhembus akan semakin kuat. Semakin menguatnya angin tenggara yang sifatnya kering menyebabkan berkurangnya curah hujan di daerah tersebut.

Hasil pengolahan data harian pasang surut 19 November 2019 menunjukkan waktu pasang dua kali yakni terjadi pada pukul 00:00 - 02.00 WIB dan terjadi lagi pasang kedua pada pukul 19.12 WIB. Sedangkan surut terendah pertama terjadi pada pukul 07.00 dan surut terendah kedua terjadi pada pukul 09.36 WIB. Hal tersebut memungkinkan terjadinya arus pasang surut yang menjadi faktor sebaran suhu permukaan laut. Arah arus pada stasiun DC hasil penelitian di lapangan cenderung bergerak ke arah Timur Laut dengan kecepatan $60-120 \mathrm{~cm} / \mathrm{s}$, sedangkan pada stasiun Suar cenderung bergerak ke arah Barat Laut dengan kecepatan awal $9 \mathrm{~cm} / \mathrm{s}$. Arah arus pada stasiun DC yang bergerak cenderung ke arah Utara-Timur Laut mempengaruhi sebaran suhu permukaan laut pada stasiun tersebut yang juga cenderung bergerak ke arah Utara-Timur Laut

Suhu akibat air bahang dengan nilai $33^{\circ}-34^{\circ} \mathrm{C}$ memiliki luas area 140,35 ha dan jarak tegak lurus pantai adalah $0,48 \mathrm{~km}$. Suhu akibat air bahang dengan nilai $34^{\circ}-35^{\circ} \mathrm{C}$ memiliki luas area 60,94 ha dan jarak tegak lurus pantai adalah 0,37 . Suhu akibat air bahang dengan nilai $35^{\circ}-36^{\circ} \mathrm{C}$ memiliki luas area 4,57 ha. Sebaran suhu permukaan laut secara spasial berdasarkan hasil penelitian lapangan 
juga menunjukkan nilai di atas $35^{\circ} \mathrm{C}$ yang menyebar ke arah Timur Laut. Kontur suhu tertinggi $>34^{\circ} \mathrm{C}$ terjadi pada mulut DC. Sedangkan kontur suhu $33^{\circ} \mathrm{C}$ menyebar di sisi Barat dan Timur dari air bahang. Sebaran suhu dengan nilai suhu $34^{\circ} \mathrm{C}$ mencapai jarak $<500 \mathrm{~m}$. Di sebalah Utara dan Timur Laut daerah penelitian, suhu permukaan laut bernilai $<33^{\circ} \mathrm{C}$. Hal tersebut dikarenakan suhu akibat air bahang terdesak oleh massa air bersuhu relatif dingin dari arah Timur, sehingga air bahang mengalir ke arah Barat Laut.

\section{KESIMPULAN}

Sebaran suhu permukaan laut berdasarkan hasil pengolahan Citra Landsat 8 TIRS perekaman 20 November 2019 cenderung bergerak ke arah Utara-Timur Laut. Hal tersebut dipengaruhi oleh pergerakan arus pasang surut berdasarkan data lapangan 20 November 2019, stasiun Discharge Canal yang juga cenderung bergerak ke arah Timur Laut dengan kecepatan arus 0.6-1.2 m/s. Hasil pengolahan Citra Landsat 8 TIRS Lapangan menunjukkan nilai SPL dengan rentang $30^{\circ-} 34^{\circ} \mathrm{C}$ pada kedalaman 0 $\mathrm{m}$ dan jarak 0-0,25 km dengan luasan total 491,35 ha. Nilai SPL di perairan tersebut dipengaruhi oleh trend IOD yang kemudian berdampak pada intenstitas curah hujan.

\section{DAFTAR PUSTAKA}

Ismayati, Q., Helmi, M dan Rochaddi, B. 2013. Kajian Spasial Suhu Permukaan Laut Akibat Air Bahang PLTU Paiton Menggunakan Saluran Termal Satelit Landsat 7/Etm+ Di Pantai Bhinor Kabupaten Probolinggo Jawa Timur. Jurnal Oseanografi., 2(1): 49-56.

Panalaran, S., Indra.B.P., Siddhi S. 2012. Kajian Penyebaran Plume Termal Outlet Air Pendingin Power Plant PT Newmont Nusa Tenggara di Perairan Teluk Benete. Jurnal Oceanography. 1(1) : 93101.

Sugiyono. 2008. Metode Penelitian Bisnis. Alfabeta: Bandung.

Triatmodjo, B. 1996. Metode Numerik. Yogyakarta: Beta Offset. 